\title{
Effects of Starvation on Hepatic and Muscular Glycogen Contents of Weaned Kids
}

\author{
Mitsuto Matsumoto and Tatsuo Hamada \\ National Institute of Animal Industry, Tsukuba \\ Norin-danchi, P. O. Box 5, Ibaraki 305
}

(Received March 31, 1982)

\begin{abstract}
The experiment was carried out using 9 Japanese meat-type kids to observe the effects of starvation on the tissue glycogen contents of weaned kids. The kids, of 12 weeks of age, were divided into 3 groups of $3 \mathrm{kids}$ each: 1) a fed group, 2) a $48 \mathrm{hr}$ starved group, 3) a $96 \mathrm{hr}$ starved group. In the fed group, glycogen contents of the liver, skeletal muscle, diaphragm and heart were $19.7 \pm 2.1,4.79 \pm 0.70,5.48 \pm 1.10$ and $6.68 \pm 0.89 \mathrm{mg}$ per gram of wet tissue weight, respectively. Total hepatic glycogen decreased by $81 \%$ and $91 \%$ in the $48 \mathrm{hr}$ and $96 \mathrm{hr}$ starved groups, respectively. Fortyeight $\mathrm{hr}$ and $96 \mathrm{hr}$ starvation reduced glycogen concentration of skeletal muscle significantly $(P<0.05)$. But in the diaphragm, there was no significant difference between the fed and $48 \mathrm{hr}$ starved groups, while glycogen concentration in the $96 \mathrm{hr}$ starved group was significantly $(P<0.05)$ lower than in the other groups. No significant differences among the 3 groups were noted in cardiac glycogen. Starvation increased plasma free fatty acids concentration significantly $(P<0.05)$. Blood plasma glucose concentration in the $96 \mathrm{hr}$ starved group was significantly $(\mathrm{P}<0.05)$ lower than in the fed group, but there was no significant difference between the $96 \mathrm{hr}$ starved and $48 \mathrm{hr}$ starved groups.
\end{abstract}

Ipn. J. Zootech. Sci., 53 (8): 574-578, 1982

In our previous papers ${ }^{1,2}$, we showed in several single-stomached animals that starvation reduces both skeletal muscle and hepatic glycogen. On the contrary, it is also well recognized that starvation increases cardiac glycogen ${ }^{1-5}$ ). These phenomena have also been observed in preruminant kids ${ }^{1}$, but little information is available for ruminant animals.

The ruminant differs from single-stomached animals, because the ruminant utilizes volatile fatty acids (VFA), the main products of carbohydrate digestion in the rumen, as its main energy source. But glucose requirement per body weight in the ruminant is nearly equal to that in the nonruminant ${ }^{6)}$, so that glucose must be synthesized from propionate, glucogenic amino acids, lactate and glycerol. Recently, it has been shown in the rat that skeletal muscle glycogen is a potentially valuable source of blood glucose during starvation"). This suggests that skeletal muscle glycogen is utilized as a source of blood glucose during starvation in the ruminant as well as in the rat.

Much work has been done on tissue glycogen in nonruminants, but the relationship between feed ingestion and tissue glycogen in the ruminant has not been clearly demonstrated. Thus, in this paper, we observed the effects of starvation on the tissue glycogen contents of the ruminant kid and discussed the role of muscular glycogen as a source of blood glucose. 


\section{Materials and Methods}

The experiment was carried out from September to December using 9 Japanese native meat-type kids. They were caged individually in a room whose temperature was kept between $15^{\circ} \mathrm{C}$ and $25^{\circ} \mathrm{C}$. They were weaned until 6 to 7 weeks of age and given commercial calf starter and rice straw ad libitum. They consumed about $250 \mathrm{~g}$ of calf starter and $25 \mathrm{~g}$ of rice straw daily.

At 12 weeks of age, they were divided into 3 groups, of 3 kids each: 1) a fed group, 2) a $48 \mathrm{hr}$ starved group and 3) a $96 \mathrm{hr}$ starved group. Water was given freely during the above starvation periods. They were killed by incision of main vessels of the neck after anesthetizing with ethyl ether. Immediately after slaughter, the liver, skeletal muscle in the femoral region, diaphragm and heart were removed and about $1 \mathrm{~g}$ of each tissue was placed into test tubes containing $2 \mathrm{ml}$ of $30 \% \mathrm{KOH}$ for subsequent glycogen analysis. Glycogen contents were determined by the anthrone method $^{\text {8) }}$.

At the time of slaughter, blood samples were collected into heparinized tubes for the determination of plasma free fatty acids (FFA) and plasma glucose concentrations. They were determined as previously described ${ }^{1)}$.

\section{Results}

At slaughter, the means of body weights and their standard errors of the fed, 48 $\mathrm{hr}$ and $96 \mathrm{hr}$ starved groups were $6,170 \pm 560,5,630 \pm 310$ and $5,820 \pm 190 \mathrm{~g}$, respectively. The body weight losses during the total starvation period were $-10 \pm 250$ and $-380 \pm$ $340 \mathrm{~g}$ for the $48 \mathrm{hr}$ and $96 \mathrm{hr}$ starved groups, respectively.

Table 1 shows the glycogen concentrations in liver, skeletal muscle, diaphragm and heart and the total hepatic glycogen content. Total hepatic glycogen decreased by $81 \%$ and $91 \%$ in the $48 \mathrm{hr}$ and $96 \mathrm{hr}$ starved groups, respectively. The ratio of glycogen of the $48 \mathrm{hr}$ starved group to that of the fed group was higher in the diaphragm than in skeletal muscle, but the ratio of glycogen of the $96 \mathrm{hr}$ starved group to that of the $48 \mathrm{hr}$ starved group was lower in the diaphragm than in skeletal muscle.

Table 1. Effect of starvation on the glycogen concentrations in the liver, skeletal muscle, diaphragm and heart and the total liver glycogen contents

\begin{tabular}{|c|c|c|c|c|c|c|}
\hline \multirow{2}{*}{ Treatment } & \multicolumn{3}{|c|}{ Liver } & \multicolumn{3}{|c|}{ Glycogen concentration } \\
\hline & $\begin{array}{c}\text { Glycogen } \\
\text { concentration }\end{array}$ & $\begin{array}{l}\text { Relative } \\
\text { size }\end{array}$ & $\begin{array}{l}\text { Total } \\
\text { glycogen }\end{array}$ & $\begin{array}{l}\text { Skeletal } \\
\text { muscle }\end{array}$ & Diaphragm & Heart \\
\hline$\therefore \quad \therefore \quad:$ & $\mathrm{mg} / \mathrm{g}$ & $\mathrm{g} / \mathrm{kg} \mathrm{EBW}$ & $\mathrm{mg} / \mathrm{kg} \mathrm{EBV}$ & W & $-(\mathrm{mg} / \mathrm{g})$ & 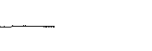 \\
\hline Fed, ad libitum & $19.7 \pm 2.1^{x, 1)}$ & $33.8 \pm 3.0^{\mathrm{a}}$ & 667 & $4.79 \pm 0.70^{\mathrm{a}}$ & $5.48+1.10^{3}$ & $6.68+0.89$ \\
\hline Starved, $48 \mathrm{hr}$ & $4.55 \pm 1.91^{\mathrm{b}}$ & $28.4 \pm 0.2^{\mathrm{a}, \mathrm{b}}$ & 129 & $2.64 \pm 0.08^{b}$ & $3.70 \pm 0.29^{a}$ & $5.92 \pm 0.32$ \\
\hline Starved, $96 \mathrm{hr}$ & $2.25 \pm 0.68^{\mathrm{b}}$ & $25.4 \pm 0.8^{\mathrm{b}}$ & 57 & $1.18 \pm 0.62^{b}$ & $0.84 \pm 0.19^{\circ}$ & $7.42 \pm 1.11$ \\
\hline
\end{tabular}

1) Mean \pm standard error of 3 kids. a, b: differences between figures with different superscript are significant at $5 \%$ level. EBW: empty body weight (body weight - contents of digestive tract). 
Table 2. Effect of starvation on blood plasma glucose and free fatty acids (FFA) concentrations

\begin{tabular}{lcc}
\hline Treatment & Glucose & F F A \\
\hline & $\mathrm{mg} / 100 \mathrm{~m} l$ & $\mathrm{mEq} / l$ \\
Fed, ad libitum & $59.6 \pm 0.6^{\mathrm{a}, 1)}$ & $0.067 \pm 0.004^{\mathrm{a}}$ \\
Starved, $48 \mathrm{hr}$ & $52.5 \pm 3.0^{\mathrm{a}, \mathrm{b}}$ & $1.41 \pm 0.28^{\mathrm{b}}$ \\
Starved, $96 \mathrm{hr}$ & $48.3 \pm 3.3^{\mathrm{b}}$ & $1.74 \pm 0.21^{\mathrm{b}}$ \\
\hline
\end{tabular}

1) Mean \pm standard error of 3 kids. $a$, b: differences between figures with different superscript are significant at $5 \%$ level,

Though the cause of these differences is not clear, the characteristics of each muscle may be a factor.

It is clearly shown in the ruminant kid as well as nonruminant animals ${ }^{1,2)}$ that starvation decreases the glycogen concentrations in the liver, skeletal muscle and diaphragm. It is shown that starvation increases cardiac glycogen ${ }^{1-5}$, but no significant difference among the three groups was noted in the cardiac glycogen in this experiment. Starvation of $96 \mathrm{hr}$ may be too short to increase cardiac glycogen.

Table 2 shows blood plasma FFA and glucose concentrations. The lowest concentration of plasma glucose was obtained in the $96 \mathrm{hr}$ starved group and the difference between the $96 \mathrm{hr}$ starved and fed groups was statistically significant $(\mathrm{P}<0.05)$. REID $^{9)}$ shows in sheep that $24 \mathrm{hr}$ or $46 \mathrm{hr}$ starvation has little effect on blood glucose concentrations and that $96 \mathrm{hr}$ starvation reduces it. This agrees with the results obtained in this experiment. Starvation induced a significant increase in plasma FFA. This results were the same as those reported by others ${ }^{1,5,10,11}$.

\section{Discussion}

The importance of hepatic glycogen for maintaining blood glucose within a normal range is well recognized. Skeletal muscle glycogen is also a potentially valuable source of blood glucose ${ }^{7)}$. About $90 \%$ of glucose residues in glycogen is released as glucose1-phosphate (G1P) during glycogenolysis by the action of glycogen phosphorylase, which phosphorolyzes the $\alpha(1-4)$ glycosidic linkage of glycogen. About 10\% of glucose residues in glycogen is released as glucose by the action of a debranching enzyme, which hydrolyzes the $\alpha(1-6)$ linkage. G1P and glucose can be metabolized to lactate by way of glycolysis. Lactate produced by glycolysis in skeletal muscle may be available for gluconeogenesis in the liver and kidneys. Accordingly, skeletal muscle glycogen may contribute to the maintenance of blood glucose at the normal level during starvation.

Supposing that $30 \%$ of body mass is skeletal muscle ${ }^{12)}$, contents of glucose residue stored in skeletal muscle as glycogen are shown in Fig. 1. About 1,600 $\mathrm{mg}$ of glucose per $\mathrm{kg}$ of empty body weight (body weight - content of digestive tract) was stored in skeletal muscle as glycogen. During $48 \mathrm{hr}$ starvation, over $700 \mathrm{mg}$ of glucose 


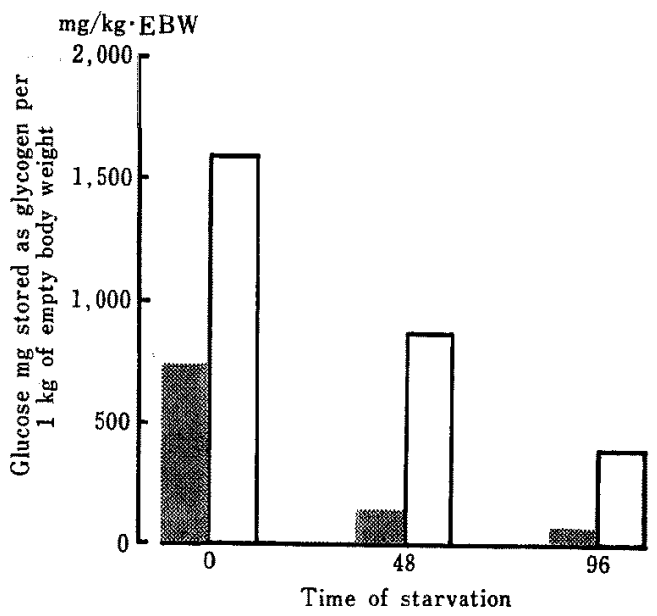

Fig. 1. Effect of starvation on total glucose residue stored as glycogen in liver (solid bar) and skeletal muscle (open bar). One $\mathrm{mg}$ of glucose residue corresponds to $0.9 \mathrm{mg}$ of glycogen. Glucose residue in the liver was calculated from liver glycogen content shown in Table 1. Glucose residue in skeletal muscle was calculated on the assumption that $30 \%$ of body mass would be skeletal muscle. The differences in glycogen contents among the different portions were ignored.

residue would be depleted from skeletal muscle, whereas $600 \mathrm{mg}$ of glucose would be depleted from the liver. The next $48 \mathrm{hr}$ starvation would deplete about $500 \mathrm{mg}$ and $80 \mathrm{mg}$ glucose from skeletal muscle and liver, respectively. These assumptions ignore the changes in the ratio of skeletal muscle to empty body weight during the starvation period and the difference in glycogen contents among the sampling portions.

Though it is not known what proportion of degraded muscle glycogen would be oxidized in the TCA cycle or what proportion would be converted into blood glucose during the starvation, skeletal muscle glycogen must contribute to the maintenance of blood glucose concentration within the normal range. Blood glucose concentration may not drop rapidly unless most skeletal muscle glycogen can be depleted.

\section{References}

1) Matsumoto, M. and T. Hamada, Jpn. J.Zootech. Sci., 51: 860-865. 1980.

2) Matsumoto, M. and T. Hamada, Jpn. J. Zootech. Sci., 52: 622-624. 1981.

3) Evans, G., J. Physiol. (London), 82: 468-480. 1934.

4) Adrouny, G. A. and J.A. Russell, Endocrinology, 59: 241-251. 1956.

5) Matsumoto, M. and R. Funabiki, J. Nutr. Sci. Vitaminol., 23: 471-474. 1977.

6) Ballakd, F. J., R. W. Hanson and D. S. Kronfeld, Fed. Proc., 28: 218-231. 1961.

7) Sugden, M. C., S. C. Sharples and P. J. Randle, Biochem. J., 160: 817-819. 1976.

8) Vies, J.V., Biochem. J., 57: 410-416. 1954.

9) ReID, R. L., Aust. J. Agric. Res., 1: 182-199. 1950.

10) DotE, V. P., J.Clin. Invest., 35: 150-154. 1956.

11) Fuller, R.W. and E. R. Diller, Metabolism, 19: 226-229. 1970.

12) Fowler, V.R., in Growth in Animals (Lawrence, T. L. J. edi.) 249-263. Butterworths. London. 1980. 


\title{
Matsumoto and HaMAda
}

\section{離乳山羊の肝臓および筋肉グリコーゲン 含量に及ほす絶食の影響}

\author{
松本光人・浜田龍夫 \\ 農林水産省畜産試験場， \\ 筑波農林研究団地, 茨城県 305
}

離乳山羊の肝臓，骨格筋，横隔膜および心筋グリニー ゲン含量に及ぼす絶食の影響を， 7 週龄までに離乳した 12 週齢の山羊 9 頭を用いて検討した。山羊は, 飽食, 48 時間絶食および 96 時間絶食の各区に 3 頭ずつ割り当て た。飽食区のグリコーゲン濃度 $(\mathrm{mg} / \mathrm{g}$, 平均士標準誤 差) は, 肝臓 $19.7 \pm 2.1$, 骨格筋 $4.79 \pm 0.70$, 横隔膜 $5.48 \pm 1.10$, 心筋 $6.68 \pm 0.89$ であった. 䀒藏の総 グ リコーゲン含量は，48時間あるいは 96 時間の絶食によ りそそれぞれ $81 \%$ ，91\%滅少した。骨格筋グリューゲン は 48 時間および 96 時間絶食区で飽食区に比して有意
(P<0.05)に低汃った：しかし，横隔膜では，96時間䋓 食によってグリコーダン濃度が有意 $(\mathrm{P}<0.05)$ 亿低下 したむのの，48 時間絶食では有意な低下は認められなか った。心筋グリコーゲン濃度には各区間に有意な差は認 められなかった，血漿遊離脂肪酸源度は，飽食区に比較 し両絶食区で有意 $(\mathrm{P}<0.05)$ に上昇した. 血墏グルコー 不浱度は，96 時間絶食区で飽食区ょり有意 $(\mathrm{P}<0.05)$ に低下したが，48時間絶食区は飽食区西るいは96時間 絶食区と比較して有意な差柱認められなかった。

日音会報，53(8)：574-578，1982 